\title{
PAI-1 and Recurrent Abortion
}

\author{
Lara $\mathrm{K}^{*}$ and De Gôes A \\ Department of Microbiology and clinical chemistry, Brazil
}

*Corresponding author: Lara K, Microbiology and clinical chemistry, Pos grade in reproductive medicine, Brazil.

Submission: 眥 Dec 23, 2017; Published: 䉑June 01, 2018

\begin{abstract}
The plasminogen activator inhibitor type-1 (PAI-1) acts negatively on the fibrinolysis process, in wich the plasminogen changes to plasmina, interrupting the fibrinolysis and favoring the thrombosis. The thrombosis is associated with recurrent spontaneous abortion (RSA), and the thromboembolism (TE), and is the main cause of maternal death during pregnancy and postpartum. The PAI-1 especiately the polymorphism $4 \mathrm{G} / 5 \mathrm{G}$ has a relation with the increased risk of venous thrombosis associated with protein deficiency S or FVL Leiden factor. It is advisable to evaluate the existence of thrombophilia in patients with a family history of ischemic manifestations, as they are related to obstetric complications.
\end{abstract}

Keywords: Recurrent spontaneous abortion; PAI-1; Thrombophilia; Thromboembolism; Venous thromboembolism; Polymorphism

\section{Introduction}

During pregnancy, there are physiological changes that favor the formation of thrombus, this being the prompting non obstetric cause of maternal mortality and morbidity.

These changes are:

A. Increase of coagulation factors: FI, FVII, FVIII, FIX, FXIII

B. Increase of platelet aggregation

C. Changes in the fibrinolytic system, caused basically.

These alterations are transitory, and disappear eight weeks after birth. But a history of thrombosis and the presence of thrombophilia, increases the risk of venous or lung thromboembolism [1]. The recurrent spontaneous abortions, are two or more consecutive miscarriages before the 12th week, and are more frequent in women with thrombophilia, this risk is also associated with thromboembolism and implantation failure [2]. Here are three polymorphisms of the gen of the inhibitor of the activator of plasminogen (PAI-1): 4G/4G, 4G/5G and 5G/5G. The polymorphism $4 \mathrm{G} / 5 \mathrm{G}$ has a higher incidence than the homozygous 4G/4G, 5G/5G. PAI-1 is the principal inhibitor physiological of the fibrinolytic process. This process prevents the deposition of excess of fibrin in the placenta, fetal vasculature and stabilizes the base of the placenta [3]. The decrease of the fibrinolytic process can be the cause of infertility and recurrent abortions.

\section{Metodology}

A bibliographic review was made, using platforms pubmed and medline. Languages: English, Spanish and Portugues.

\section{Results and Discussion}

Due to inconsistencies in studies of PAI-1 and its association with recurrent abortion, Yuejiao Li et al, made a meta-analysis based on two inclusion criteria: 1-case-control studies, 2-studies with enough data to calculate the frequency of allele-genotype. Twenty two studies were included. A positive association was found in Caucasian population, but no association was found for Asian and Latino population. It shows us that different ethnic groups have different frequencies, and they lead to different results, besides that only one study in the Latino population was included.

Another meta-analysis, was made by [9], they used new and more rigorous inclusion criteria: 1-evaluate the association between PAI-1 4G/5G with the risk of recurrent abortion, 2-studies case- control, our projected with cohort 3-Studies with enough information to infer results. This analysis showed that there is an association of PAI-1 4G/5G with recurrent abortion in Caucasians, Asians and Africans, but not in Latinos. Also with three spontaneous abortions, there was no difference between them, the $4 \mathrm{G} / 5 \mathrm{G}$ polymorphism, conferring an increased risk to both groups. In summary, this meta-analysis found a positive association between the 4G/5G PAI-1 polymorphism and the increased risk of recurrent miscarriage in Caucasian, African and Asian populations. In addition, effective therapeutic prevention can theoretically be developed by focusing on anticoagulation and improving genetic polymorphism studies in recurrent miscarriages.

Only one study of all the analysis showed no association of PAI-1 and recurrent abortion. It was done by Arabi et al. [8]. We 
wanted to demonstrate this association of PAI-1 and angiotensin I converting enzyme (ACE). Due to heterogeneity in the groups included, it was not possible to demonstrate the relationship of PAI1 with recurrent abortions, but there was a relationship with ACE. Khosravi [4] study focused in detail on the comparison of $4 \mathrm{G} / 5 \mathrm{G}$ polymorphism with recurrent failure and implantation failure.

The study with women with recurrent miscarriage plus two implantation failure. One hundred women with at least two normal live births were included in the control group. The results showed an increase in the PAI-1 4G allele in the three subgroups, significantly higher than in the control group. In several studies therapeutic perspectives are suggested for women with PAI polymorphism, which sometimes is accompanied by other thrombophilias and/or other pathologies, for example the application of metformin in case of polycystic, heparin and aspirin [4,5].

According to a study by [5] on congenital thrombophilia, its reproductive impact and treatment prospects, PAI-1 polymorphism has an uncertain risk, together with protein $\mathrm{S}$ deficiency, factor XIII, factor VIII increase, protein C receptor polymorphism. Thrombophilias within this group, 100 grams of aspirin daily and follow up with Doppler of uterine arteries and fetal growth are recommended. Evidence indicates that an increase in PAI-1 levels increases the risk of recurrent abortion and complications during pregnancy, such as pre-eclampsia among others [5].

\section{Conclusion}

In conclusion, there may be association with recurrent abortions and PAI-1 (4G/5G). However, large and prospective studies are needed to validate this result. According to the literature evaluated, in the present study, it was demonstrated that the homozygous heterozygote $4 \mathrm{G} / 4 \mathrm{G}$ PAI-1 and $4 \mathrm{G} / 5 \mathrm{G}$ should be considered as a risk factor and its investigation should be considered in cases of implantation failure and/or recurrent abortions.

\section{References}

1. Jaume AR, Raventos FJC (2005) Trombofilia congénita y aborto recurrente: estrategia diagnósticas y recomendaciones terapéuticas. Med Cin (Barc) 125(16): 626-631.

2. Kupferminc MJ, Eldor A, Steinman N, Many A, Bar-Am A, et al. (1999) Increased frequency of genetic thrombophilia in women with complications of pragnency. N Engl J Med 340(1): 9-13.

3. Mei-Tzu Su, Sheng HL, Yi-Chi Chen, Pao-lin K (2013) Genetic association studies of ACE and PAI-1 genes in women with recurrent pregnancy loss. Throm Haemost 109(1): 8-15.

4. Khosravi F, Zarei S, Ahmadvand N, Akbarzadeh PZ, Savai E, et al. (2014) Association beween plasminogen activator inhibitor 1 gene mutation and different subgroups of recurrent miscarriage and implantation failure. J Assist Reprod Genet 31(1): 121-124.

5. Kujovich JL (2004) Thrombophilia and pregnancy complications. Am J Obstet Gynecol 191(2): 412-424.

6. Rodrigo SA, Andrés PG, Alfredo M, Germanin A (2007) Trombofilias Congénitas Impacto Reproductivo y Perspectivas de Tratamiento. Rev Med Clin. Condes 18(4): 383-393.

7. Bar JB, Brenner Ellis M, Yarom I, Yohaid D (2005) Effects of enoxaparin on late pregnancy complications and neonatal outcome in women with recurrent pregnancy loss and thrombophilia: results from the Live-Enox study. Fertil Steril 84(3): 770-773.

8. Aarabi M, Memariani T, Arefi S, Aarabi M, Hantoosh ZS, et al. (2011) Polymorphisms of plasminogen activator inhibitor-1, angiotensin converting enzyme and coagulation factor XIII genes in patients with recurrent spontaneous abortion. J Matern Fetal Neonatal Med 24(3): 545-548.

9. Huang BS, Xuehua BS, Zhao, Chen Q, Li M, et al. (2017) Plasminogen Activator inhibitor-I polymorphism confers a genetic contribution to the risk of recurrent spontaneous abortion: An updated meta-analysis. Reproductive Sciences 24(11): 1551-1560.

10. Irma, Miranda, Sainz, Maldonado, Sánchez (2009) Asociación entre el polimorfismo 4G/5G en el gen del inhibidor del activador del plasminoêgnio-1 (PAI-1) y el infarto agudo de miocardio con elevación del ST en pacientes jóvenes. Esp Cariol 62: 365-372.

11. Ivanov P, Tsvyatkovska T, Konova E, Komsa-Penkova R (2012) Inherited thrombophilia and IVF failure: the impact of coagulation disorders on implantation process. Am J Reprod Immunol 68(3): 189-198.

12. Leila S, Zahra N, Ashraf A, Aghahosseini M, Rashidi M, et al. (2014) Recurrent IVF failure and hereditary thrombophilia. Iran J Reprod Med 12(7): 467-470.

13. Palomba S, Orio F , Falbo A, Russo T, Tolino A, et al. (2005) Plasminogen activator inhibitor 1 and miscarriage after metformin treatment and laparoscopic ovarian drilling in patients with polycystic ovary syndrome. Fertil Steril 84(3): 761-765.

14. Sartori MT, Wiman B, Vettore S, Dazzi F, Girolami A, et al. (1998) 4G/5G polymorphism of PAI-1 gene promoter and fibrinolytic capacity in patients with deep vein thrombosis. Thromb Haemost 80(6): 956-960.

15. Vanoni S (2004) Embarazo y tromboembolismo pulmonar. Rev Argent Med Resp 1: 6-11.

16. Wang Y, Long J, Wang X, Sun Y (2014). Association of the plasminogen activator inhibitor-1 (PAI-1) Gene-675 4G/5G and-844 A/G promoter polymorphism with risk of keloid in a Chinese population. Med Sci Monit 20: 2069-2073.
Creative Commons Attribution 4.0

International License

For possible submissions Click Here

\section{Submit Article}

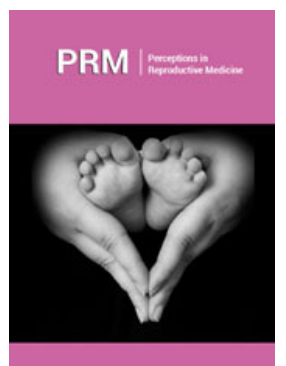

\section{Perceptions in Reproductive Medicine}

\section{Benefits of Publishing with us}

- High-level peer review and editorial services

- Freely accessible online immediately upon publication

- Authors retain the copyright to their work

- Licensing it under a Creative Commons license

- Visibility through different online platforms 